\title{
The first results of national antimicrobial resistance surveillance system in Turkey
}

\section{Türkiye'de ulusal antimikrobiyal direnç surveyans sisteminin ilk sonuçları}

\author{
Nilay ÇÖPLÜ1 , Hüsniye ŞiMŞEK², Deniz GÜR ${ }^{3}$, Ayşegül GÖZALAN ${ }^{4}$, Ufuk HASDEMiR ${ }^{5}$, \\ Zeynep GÜंLAY', Gülçin BAYRAMOĞLU7 ${ }^{7}$ Nezahat GÜRLER, Şöhret AYDEMIR ${ }^{9}$, \\ Mete EYIGÖR ${ }^{10}$, Duygu PERÇiN ${ }^{11}$, Dilber AKTAŞ ${ }^{2}$
}

\section{ABSTRACT}

Objective: In order to combat with antimicrobial resistance, some measures should be taken and determination of the current status is one of them. National antimicrobial resistance surveillance system (NAMRSS) was established for this purpose in Turkey. It was targeted to be useful for guidence of ampirical therapy, create antimicrobial usage policies, provide data to the guidebooks, and supply initial information to evaluate the efficasy of the measures taken.

Methods: Data of resistance was collected from 55 hospital, from blood and cerebrospinal fluid isolates, which were S. aureus, E. faecalis and E. faecium, S. pneumoniae, E. coli, K. pneumoniae and $P$. aeruginosa. The antimicrobials and test methods were chosen in accordance with international surveillance systems. The collected data was analysed by WHONET software.

Results: S. aureus (1437); meticillin resistance was $31.5 \%$, rifampin, linezolid and vancomycin resistance

\section{ÖZET}

Amaç: Antimikrobiyal direnç ile mücadele için bazı önlemler alınmalıdır, mevcut durumun saptanması da bunlardan biridir. Türkiye'de ulusal antimikrobiyal direnç surveyans sistemi bu hedefle kurulmuştur. Ampirik tedaviyi desteklemek, antimikrobiyal kullanım politikaları oluşturmak, rehber kitaplara veri sağlamak, alınmış olan önlemlerin etkinliğini değerlendirmek için başlangıç bilgilerini sağlamak amaçlanmıștır.

Yöntem: Elli beș hastaneden, kan ve beyin omurilik sıvısından izole edilen Staphylococcus aureus, Enterococcus faecalis, Enterococcus faecium, Streptococcus pneumoniae, Escherichia coli, Klebsiella pneumoniae ve Pseudomonas aeruginosa izolatlarının direnç verileri toplanmıștır. Antimikrobiyaller ve test yöntemleri uluslararası surveyans sitemleri ile uyumlu olacak șekilde seçilmiștir. Toplanan veriler WHONET programı ile analiz edilmiștir.

Bulgular: S. aureus ( $n=1437)$; metisilin direnci $\% 31,5$, rifampin, linezolid ve vankomisin direnci sırası

'Kastamonu University, Kastamonu Medical School, Microbiology Department, Kastamonu

${ }^{2}$ Turkish Public Health Institute, Microbiology Reference Laboratories Directorate, Ankara

${ }^{3}$ Hacettepe University, School of Medicine, Department of Microbiology, Ankara

${ }^{4}$ Ankara Ataturk Training and Research Hospital, Department of Microbiology, Ankara

${ }^{5}$ Marmara University, School of Medicine, Department of Microbiology, Istanbul

${ }^{6}$ Dokuz Eylül University, School of Medicine, Department of Microbiology, İzmir

${ }^{7}$ Karadeniz Technical University, School of Medicine, Department of Microbiology, Trabzon

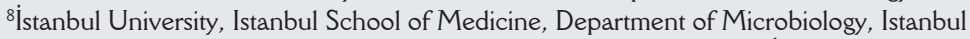

${ }^{9}$ Egean University, School of Medicine, Department of Microbiology, İzmir

${ }^{10}$ Akdeniz University, School of Medicine, Department of Microbiology, Antalya

${ }^{1}$ Erciyes University, School of Medicine, Department of Microbiology, Kayseri 
were $65.3 \%, 2.3 \%$, and $0.0 \%$, respectively. E. faecalis $(\mathrm{n}=760)$ resistance of ampicillin was 9.7\%, linezolid, vancomycin, teicoplanin were lower than $1 \%$, high level $(\mathrm{HL})$ aminoglycoside was around $30 \%$. E. faecium $(\mathrm{n}=756)$ resistance of ampicillin was $88,1 \%$, linezolid, teicoplanin were lower than $1 \%$, vancomycin $17 \%$, HL aminoglycoside was around $50 \%$. S. pneumoniae $(n=128)$ with non-meningitis breakpoints; resistance were lower than $5.2 \%$ for all antimicrobials other than erythromycin (32\%), with meningitis breakpoints: resistance increased to $14,3-44,8 \%$. E. coli (2280) and K. pneumoniae (1307), extended spectrum beta-lactamase (ESBL) was $51.6 \%$ and $54.0 \%$, respectively. $P$. aeruginosa (825) resistance were changed in between $8.4 \%$ (amikacin) and $36.4 \%$ (piperacillin).

Conclusion: The resistance was higher among the countries in close geographical region and increased in time, indicating the need for developing policies to combat with it. Besides, the results will also be valuable to monitor the usefulness of the measures taken.

Key Words: Drug resistance, microbial, surveillance, Turkey ile $\% 65,3 ; \% 2,3$ ve $\% 0,0$, bulunmuștur. E. faecalis $(\mathrm{n}=760)$ ampisilin direnci \%9,7, linezolid, vankomisin, teikoplanin direnci \%1'in altında, yüksek düzey (YD) aminoglikozid \%30 civarında bulunmuștur. E. faecium ( $\mathrm{n}=756)$ ampisilin direnci \%88,1; linezolid ve teikoplanin $\% 1$ 'den az, vankomisin \%17, YD aminoglikozid \%50 civarında bulunmuștur. S. pneumoniae $(n=128)$ nonmenenjit sınır değerler için eritromisin (\%32) dıșında tüm antimikrobiyaller için direnç \%5,2'den düșüktür, menejit sınır değerler için direnç \%14,3-44,8'a yükselmiștir. $E$. coli (2280) ve K. pneumoniae (1307) için genișlemiş spektrumlu beta-laktamaz (GSBL) direnci sırası ile $\% 51,6$ ve $\% 54,0$ bulunmuștur. $P$. aeruginosa (825) direnci \%8,4 (amikacin) ve \%36,4 (piperacillin) arasında değișmektedir.

Sonuç: Direnç Türkiye'ye yakın coğrafyadaki ülkelerden yüksek bulunmuș ve zaman içinde artış göstermiș olup bununla mücadele için politikalar geliștirmek gerektiğine ișaret etmektedir. Ayrıca, alınan önlemlerin yararııı̆ını izlemek için de sonuçlar değerli olacaktır.

Anahtar Kelimeler: Antimikrobiyal direnç, surveyans, Türkiye

\section{INTRODUCTION}

Antimicrobial drug resistance is a growing problem worldwide. To combat this problem, policies for the use of the rational antimicrobial drugs should be developed. Determination and monitoring of the current situation is one of the steps to be taken for this purpose $(1,2)$. NAMRSS was established for determination of the current status, and it will be possible to follow the efficiency of the measures taken, as well (3). Establishment of NAMRSS was based on the regulations published in the official gazete. The activities of the establishment phase were carried out with the contributions of the scientific advisory committee (SAC) consisting of 17 senior scientist (3). The clinical material, bacteria, antimicrobial agents and test methods were chosen to be in accordance with international surveillance systems like European Antimicrobial Resistance Surveillance Network (EARS-Net) because to be included in these systems in the future was targeted (4). As a matter of fact, it was included in the network of Central Asian and Eastern European Surveillance of Antimicrobial Resistance (CAESAR) in 2014 (5). During establishment, the choice of the laboratories was made regarding distribution to 12 Statistical Region Units in Turkey determined by Turkish Statistical Institute, distribution to university, training and 
research and govermental hospitals, and capability of performing blood culture and antimicrobial susceptibility tests (AST). For this purpose, a questionnary study was conducted nationwide, and 78 laboratories have been selected to participate the system $(6,7)$. By the contribution of the SAC, the standard operating procedures (SOP) and the software program were determined and published as a book $(3,8,9)$. Serial courses have been organised for the participating laboratories, in addition to external quality assurance, laboratory proficiency assesment and on-site observation studies, and the data of the system was observed to be reliable $(10,11)$.

The aim of this study was to analyse the resistance data of NAMRSS, those belong to the bacteria isolated from blood and cerebrospinal fluid (CSF), against the selected antimicrobial agents. This analysis will not only be useful for guidence of ampirical therapy, but also to create antimicrobial usage policies, to provide data to the guidebooks written for this purpose, supply initial information so that the efficasy of the measures taken can be evaluated in the long run.

\section{MATERIAL and METHOD}

Data was requested from 78 selected hospitals those were distributed to 12 regions according to Statistical Classification of Regional Units of Turkish Statistical Institute and expected to be sent quarterly. (6) Among these 55 hospital sent data, and distribution of them to the regions and institutions are shown in Figure 1. Distribution according to institutions for university, education and research and state hospital were 28,13 and 14 , respectively (Figure 1). This is a sentinel study and does not represent the regions. Data were collected by either Excel or Backlink interface programme, and analysed by WHONET $(3,9)$.

The collected resistance data of the selected bacterial species, clinical samples, antimicrobials and test methods were: Staphylococcus aureus (blood): cefoxitin disk diffusion or oxacillin minimum inhibitory consentration (MIC), if not susceptible confirmation tests (PCR mecA gen or PBP2a agglutination or MIC of oxacillin), vancomycin MIC, linezolid, rifampin; Enterococcus faecalis and Enterococcus faecium (blood): amoxicillin and/or ampicillin, $\mathrm{HL}$ gentamicin ve streptomycin, vankomycin MIC and teicoplanin MIC and if resistant confirmation by PCR, linezolid; Streptococcus pneumoniae (blood and CSF): oxacillin disk $(1 \mu \mathrm{g})$, if not susceptible penicillin MIC, cefotaxime/ceftriaxone MIC, erythromycin, norfloxacin screening, if not susceptible: ciprofloxacin and/or ofloxacin and/or levofloxacin MIC; Escherichia coli and Klebsiella pneumoniae (blood and CSF): amino-penicillin (amoxicillin and/or ampicillin), aminoglycoside (gentamicin and/or tobramycin and/ or amicasin), fluoroquinolone (ciprofloxacin and/or ofloxacin and/or levofloxacin and nalidixic acid), 3rd generation cephalosporins (cefotaxime or ceftriaxone and ceftazidim), if 3 rd generation cephalosporins are not susceptible ESBL detection, if tested: imipenem/ meropenem, piperacillin-tazobactam, co-trimoxazole (TMP/SXT); Pseudomonas aeruginosa (blood and CSF): piperacillin and/or piperacillin-tazobactam, ceftazidim, imipenem and meropenem, ciprofloxacin and/or levofloxacin, gentamicin and/or tobramycin and/or amikacin $(3,8)$.

Tests have been studied by the microbiology laboratories of the selected hospitals. Blood culture were inoculated to automatize systems (Bactec Becton Dickinson; Bact/alert BioMerieux), the signaling blood cultures were passaged and CSF were inoculated to routine media, for identification the automatize systems which were Phoenix (Becton Dickinson), Vitek MS (BioMerieux), Microscan Diagnostic (Siemens) or the conventional tests those were commented in SOP documentation were studied (3). Antimicrobial susceptibility tests were studied and evaluated according to Clinical and Laboratory Standards Institute (CLSI) standards and tests were done by Kirby Bauer disk diffusion, antibiotic 

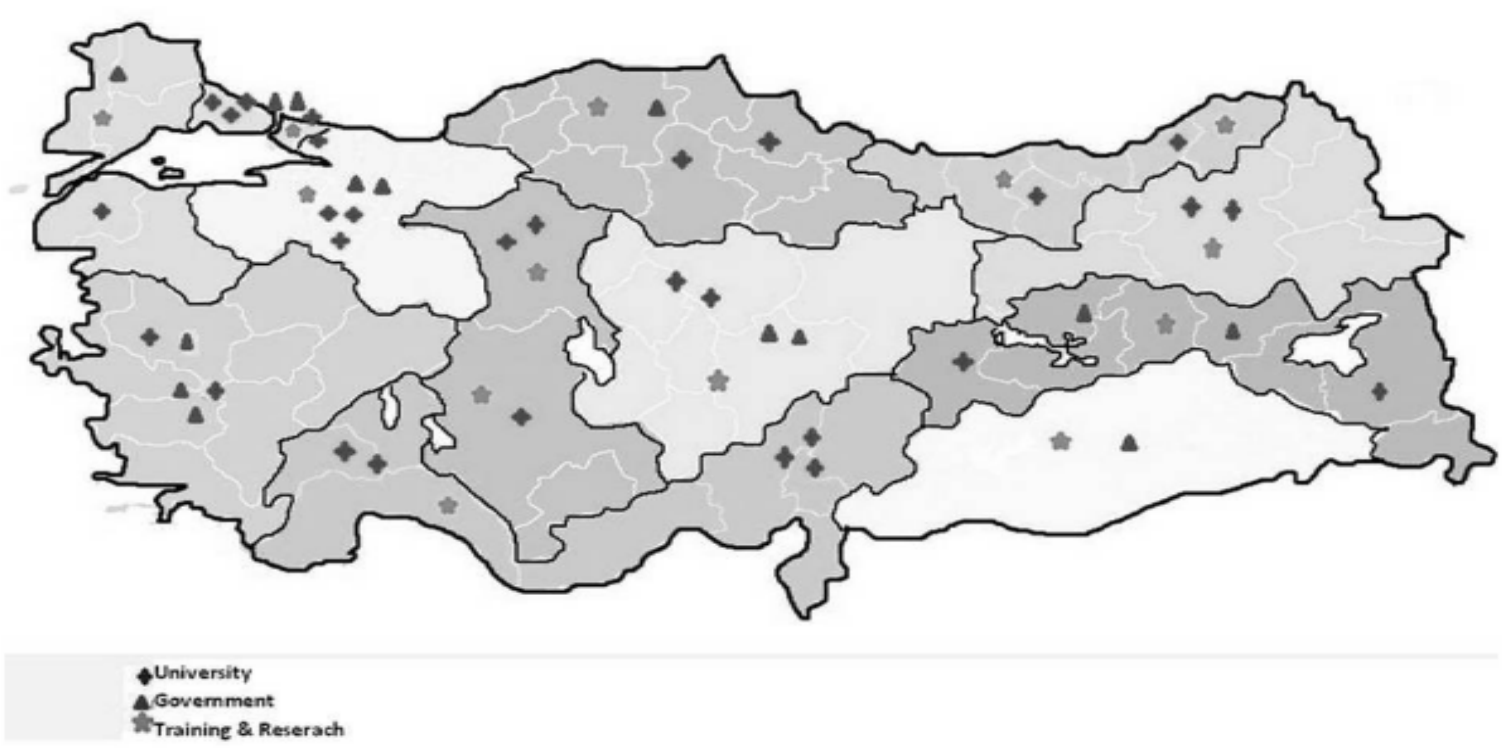

Figure 1. Distribution of the participating laboratories of university, governmet, and training and research hospitals those sent data to NAMDSS from 12 NUTS region of Turkey

gradient strip test and/or automatize systems afore mentioned.

\section{RESULTS}

The distribution of the resistance percentages of the isolates according to clinical material, and the patients gender, age group and service were shown in Table 1. For S. pneumoniae $85.6 \%$ and for the others more than $95 \%$ were isolated from blood cultures. When distribution of isolates to the patients regarded, women/men were very close to each other where more than $75.4 \%$ were adults according to age groups. Higher percentages were isolated from intensive care unit (ICU), and internal services showed higher percentages than surgical services. Paediatrics and emergency services had lower percentages than surgical services (Table 1 ).

The resistance percentages of S. aureus (1437) strains were presented in Table 2. MIC of oxacillin could be studied in 887 of the strains and $31.5 \%$ $(n=280)$ of them were meticillin resistant S. aureus
(MRSA). Among these rifampin, linezolid and vancomycin resistance percentages were 65.3\%, $2.3 \%$, and $0.0 \%$, respectively, and it was observed that except vancomycin, the resistange percentages of the other antimicrobials have been increased. When the services was regarded, it was seen that MRSA and rifampin resistance percentages were the highest in ICU and surgical services, and on the contrary, the number of the isolates were the highest in internal services which was followed by ICU and surgical services.

The resistance percentages of $E$. feacalis $(n=760)$ and $E$. faecium $(\mathrm{n}=756)$ isolates were presented in Table 3. For $E$. faecalis isolates resistance of linezolid, vancomycin and teicoplanin were lower than 1\%, but high level ( $\mathrm{HL}$ ) aminoglycoside resistance was present almost in one over three isolates. On the other hand, resistance of ampicillin and vancomycin for $E$. faecium were $88.1 \%$ and $17 \%$, respectively, and the other antimicrobials had higher resistance percentages than $E$. faecalis. Among vancomycin resistant E. faecium $(n=107)$ the resistance percentages of ampicillin, HL- gentamicin, 
Table 1. Distribution of the resistance percentage of the isolates according to clinical material, gender, age group and the services

\begin{tabular}{|c|c|c|c|c|c|c|c|c|c|c|c|c|}
\hline \multirow{2}{*}{$\begin{array}{l}\text { Bacteria } \\
\text { (n) } \\
\%\end{array}$} & \multicolumn{2}{|c|}{$\begin{array}{l}\text { S.aureus } \\
\mathrm{n}=1437\end{array}$} & \multicolumn{2}{|c|}{$\begin{array}{l}\text { E.faecalis } \\
\qquad n=760\end{array}$} & \multicolumn{2}{|c|}{$\begin{array}{l}\text { E.faecium } \\
\qquad n=756\end{array}$} & \multirow[t]{2}{*}{$\begin{array}{l}\text { S.pneumoniae } \\
\qquad \mathrm{n}=128\end{array}$} & \multicolumn{2}{|c|}{ E.coli $\mathrm{n}=\mathbf{2 2 8 0}$} & \multicolumn{2}{|c|}{$\begin{array}{c}\text { K.pneumoniae } \\
n=1307\end{array}$} & \multirow[t]{2}{*}{$\begin{array}{l}\text { P.aeruginos } a \\
\qquad \mathrm{n}=825\end{array}$} \\
\hline & & MRSA & & VRE & & VRE & & & GSBL & & GSBL & \\
\hline \multicolumn{13}{|c|}{ Clinical material } \\
\hline Blood & 97.7 & 99.1 & 984 & 100.0 & 98.0 & 95.0 & 85.6 & 99.4 & 99.3 & 98.7 & 98.2 & 97.1 \\
\hline $\mathrm{CSF}^{*}$ & 2.3 & 0.9 & 16 & 0.0 & 2.0 & 5.0 & 14.4 & 0.6 & 0.7 & 1.3 & 1.8 & 2.9 \\
\hline \multicolumn{13}{|l|}{ Gender } \\
\hline Female & 43.8 & 39.2 & 49.7 & 57.1 & 44.7 & 46.0 & 40.5 & 48.2 & 46.2 & 42.8 & 43.6 & 47.6 \\
\hline Male & 56.2 & 61.8 & 50.3 & 42.9 & 55.3 & 54.0 & 59.5 & 51.8 & 53.8 & 57.2 & 56.4 & 52.4 \\
\hline \multicolumn{13}{|l|}{ Age Group } \\
\hline New born & 4.3 & 1.8 & 1.8 & 0.0 & 1.6 & 1.8 & 1.6 & 1.5 & 1.0 & 5.6 & 8.6 & 1.1 \\
\hline Children & 11.6 & 8.0 & 11.2 & 14.3 & 17.5 & 21.4 & 20.3 & 9.3 & 9.7 & 19.0 & 25.5 & 11.5 \\
\hline Adult & 84.1 & 90.2 & 87.0 & 85.7 & 80.9 & 76.8 & 78.1 & 89.2 & 89.3 & 75.4 & 65.9 & 87.4 \\
\hline \multicolumn{13}{|l|}{ Service } \\
\hline $\mathrm{ICU} †$ & 26.8 & 54.7 & 40.7 & 42.9 & 38.1 & 48.4 & 15.2 & 16.7 & 18.4 & 32.4 & 34.2 & 42.2 \\
\hline $\begin{array}{l}\text { Internal } \\
\text { services }\end{array}$ & 45.5 & 25.6 & 30.8 & 42.9 & 33.6 & 20.2 & 45.5 & 50.7 & 48.8 & 33.5 & 24.0 & 31.5 \\
\hline $\begin{array}{l}\text { Surgical } \\
\text { services }\end{array}$ & 9.1 & 9.4 & 15.7 & 0.0 & 11.8 & 12.9 & 3.8 & 15.7 & 18.9 & 10.0 & 8.8 & 14.1 \\
\hline Pediatrics & 8.2 & 6.0 & 5.2 & 0.0 & 11.2 & 12.1 & 13.6 & 5.8 & 6.7 & 13.0 & 19.3 & 6.6 \\
\hline Emergency & 5.6 & 2.6 & 2.6 & 0.0 & 1.8 & 0.0 & 18.2 & 8.7 & 6.6 & 4.3 & 3.8 & 3.7 \\
\hline Others & 4.8 & 1.7 & 5.0 & 14.3 & 3.4 & 6.5 & 3.8 & 2.4 & 0.6 & 6.8 & 9.9 & 1.9 \\
\hline
\end{tabular}

*cerebro spinal fluid $\quad$ Intensive care unit

Table 2. Antimicrobial resistance percentage of $S$. aureus $(n=1437)$ isolates

\begin{tabular}{|c|c|c|c|c|c|}
\hline Antimicrobial & Isolate $(\mathbf{n})$ & $\mathbf{R} \%$ & I\% & S\% & R 95\% - C.I.\% \\
\hline Rifampin & 930 & 17.9 & 0.4 & 81.8 & $15.4-20.4$ \\
\hline Linezolid & 1050 & 1.0 & 0.0 & 99.0 & $0.5-1.9$ \\
\hline Vancomycin & 881 & 0.0 & 0.0 & 100.0 & $0.0-0.0$ \\
\hline
\end{tabular}


Table 3. Antimicrobial resistance percentages of $E$. faecalis $(\mathrm{n}=760)$ and $E$. faecium $(\mathrm{n}=756)$ isolates

\begin{tabular}{|l|c|c|c|c|c|c|}
\hline \multirow{2}{*}{ Antimicrobial } & Enterococcus spp. & Isolate(n) & R\% & I\% & S\% & R 95\% - C.I.\% \\
\hline \multirow{3}{*}{ Ampicillin } & E.faecalis & 626 & 9.7 & 0.0 & 90.3 & $7.6-12.4$ \\
\cline { 2 - 7 } & E.faecium & 589 & 88.1 & 0.0 & 11.9 & $85.1-90.5$ \\
\hline \multirow{3}{*}{ Gentamicin-HL* } & E.faecalis & 476 & 29.2 & $0.6^{*}$ & 70.2 & $25.2-33.5$ \\
\cline { 2 - 7 } & E.faecium & 486 & 52.3 & 0.0 & 47.7 & $47.8-56.8$ \\
\hline \multirow{3}{*}{ Streptomycin-HL } & E.faecalis & 219 & 31.1 & $1.8^{*}$ & 67.1 & $25.1-37.7$ \\
\cline { 2 - 7 } & E.faecium & 253 & 49.0 & $2.0^{*}$ & 49.0 & $42.7-55.3$ \\
\hline \multirow{3}{*}{ Linezolid } & E.faecalis & 528 & 0.4 & 1.1 & 98.5 & $0.1-1.5$ \\
\hline \multirow{2}{*}{ Vancomycin } & E.faecium & 495 & 0.6 & 2.8 & 96.6 & $0.2-1.9$ \\
\hline \multirow{2}{*}{ Teicoplanin } & E.faecalis & 666 & 0.9 & 0.6 & 98.5 & $0.4-2.1$ \\
\cline { 2 - 7 } & E.faecium & 630 & 17.0 & 0.8 & 82.2 & $14.2-20.2$ \\
\cline { 2 - 7 } & E.faecalis & 457 & 0.3 & 0.6 & 99.1 & $0-1.4$ \\
\hline
\end{tabular}

*High Level

HL-streptomycin, linezolid, and teicoplanin were $98.5 \%$; 75.6\%; $46.7 \% ; 2.8 \%$; and $95.3 \%$, respectively and resistance percentages were increased in this group. Regarding the services, for $E$. faecalis / $E$. faecium the highest resistance for vancomycin and teicoplanin were observed in neonatology, and for ampicillin in hematology and oncology.

The antimicrobail resistance percentages for S. pneumoniae $(n=128)$ were presented in Table 4. Blood isolates were $85.6 \%$ of the total, however, for penicillin G, ceftriaxone and cefotaxime, the breakpoint of both meningitis and non meningitis were evaluated for all of the isolates. When evaluated with non-meningitis breakpoints, the resistance percentages were lower than $5.2 \%$ for all of the antimicrobials other than erythromycin, and when evaluated with meningitis breakpoints it was observed that the resistance percentages increased to $14.3-44.8 \%$ (Table 4). Among the penicillin resistant isolates, 20 of them have been studied for the other antimicrobials, and for cefotaxime for meningitis, resistance and intermediate increased to $26.7 \%$ and $33.3 \%$, respectively. Similarly, erythromycin resistance was observed in 13 izolates those were penicillin resistant.

The antimicrobial resistance percentages for $E$. coli (2280) and K. pneumoniae (1307) were presented in Table 5, where the resistance percentages for the same antimicrobials among ESBL positive $927 \mathrm{E}$. coli (51.6\%) and 506 K. pneumoniae (54.0\%) isolates were presented, as well. In this table intermediate strains were added to resistant group, and susceptible group was not presented. The resistance percentages of the extended spectrum beta-lactamase (ESBL) positive group is higher than the total for all of the antimicrobials including those which does not have beta-lactam ring and effective with other mechanisms, as expected. On the other hand, when $K$. pneumoniae isolates compared to $E$. coli isolates, beta-lactam antimicrobials and amikacin showed higher resistance, trimethoprim/sulfamethoxazole nearly the same, and the others showed lower resistance for $K$. pneumoniae. However the difference was low, mostly in fluoroquinolones with 24.9\% difference which is the higest (Table 5).

The antimicrobail resistance percentages for $P$. 
Table 4. Antimicrobial resistance percentages of $S$. pneumoniae $(n=128)$ isolates

\begin{tabular}{|l|c|c|c|c|c|c|}
\hline Antimicrobial & Site of Infection & Isolate(n) & R\% & I\% & S\% & R 95\% - C.I.\% \\
\hline Penicillin G* & Non meningitis $\dagger$ & 58 & 5.2 & 6.9 & 87.9 & $0.0-40.2$ \\
\hline Penicillin G & Meningitis $†$ & 58 & 44.8 & 0.0 & 55.2 & $31.9-58.3$ \\
\hline Ceftriaxone & Non meningitis $\dagger$ & 14 & 0.0 & 21.4 & 78.6 & $0.0-26.8$ \\
\hline Ceftriaxone & Meningitis $†$ & 14 & 21.4 & 21.4 & 57.2 & $5.7-51.2$ \\
\hline Cefotaxime* & Non meningitis $\dagger$ & 41 & 0.0 & 14.6 & 85.4 & $0.0-69.0$ \\
\hline Cefotaxime & Meningitis $†$ & 41 & 14.3 & 23.8 & 61.9 & $6.0-29.2$ \\
\hline Levofloxacin & & 78 & 2.6 & 0.0 & 97.4 & $0.5-9.9$ \\
\hline Erythromycin & & 100 & 32.0 & 2.0 & 66.0 & $23.2-42.2$ \\
\hline
\end{tabular}

*Penicillin G. ceftriaxone. cefotaxim. have been studied by determination of MIC values. others either disk diffusion or MIC determination. †The breakpoint of the antimicrobial is changed by the site of infection which cause difference in the percentage of resistance.

Table 5. Antimicrobial resistance percentage of E.coli $(n=2280)$; ESBL positive E.coli $(n=927)$ and $K$. pneumoniae $(n=1307)$; ESBL positive K.pneumoniae $(n=506)$ isolates. (Intermediate have been added to resistant.)

\begin{tabular}{|c|c|c|c|c|}
\hline \multirow[t]{2}{*}{ Antimicrobial } & \multicolumn{2}{|c|}{ E. coli } & \multicolumn{2}{|c|}{ K. pneumoniae } \\
\hline & Isolate $(n)$ & $\mathbf{R} \%$ & Isolate (n) & $\% R$ \\
\hline Ampicillin & 1073 & 77.5 & & \\
\hline Ampicillin (ESBL +) & 458 & 98.0 & & \\
\hline Ceftazidime* $^{*}$ & 1536 & 37.8 & 850 & 49.3 \\
\hline Ceftazidime $(\mathrm{ESBL}+)$ & 607 & 76.0 & 313 & 84.3 \\
\hline Ceftriaxone* & 581 & 55.7 & 272 & 58.7 \\
\hline Ceftriaxone * $(\mathrm{ESBL}+)$ & 263 & 96.0 & 101 & 97.0 \\
\hline Cefotaxime* & 1306 & 49.2 & 794 & 57.6 \\
\hline Cefotaxime* $(\mathrm{ESBL}+)$ & 493 & 91.0 & 284 & 95.1 \\
\hline Amikacin & 1701 & 5.3 & 980 & 9.1 \\
\hline Amikacin (ESBL +) & 666 & 7.0 & 365 & 14.4 \\
\hline Gentamicin & 1712 & 30.8 & 957 & 27.7 \\
\hline Gentamicin (ESBL +) & 640 & 51.0 & 343 & 45.1 \\
\hline Tobramycin & 105 & 42.9 & 69 & 31.9 \\
\hline Tobramycin (ESBL +) & 54 & 65.0 & & \\
\hline Ciprofloxacin & 1249 & 47.2 & 772 & 35.7 \\
\hline Ciprofloxacin (ESBL +) & 410 & 72.0 & 269 & 52.2 \\
\hline Levofloxacin & 1088 & 49.7 & 573 & 31.2 \\
\hline Levofloxacin (ESBL +) & 458 & 72.0 & 218 & 47.1 \\
\hline TMP/SXT & 688 & 58.0 & 498 & 54.8 \\
\hline TMP/SXT (ESBL +) & 229 & 75.0 & 177 & 78.0 \\
\hline
\end{tabular}

*For E. coli 149 isolate. for K. pneumoniae 69 isolate have been studied for both of the cephalosporins. Other isolates have been studied either one of the cephalosporin . 
Table 6. Antimicrobial resistance percentages of $P$. aeruginosa $(n=825)$ isolates

\begin{tabular}{|l|c|c|c|c|c|}
\hline Antimicrobial & Isolate $(\mathbf{n})$ & $\mathbf{R} \%$ & I\% & S\% & R 95\% - C.I.\% \\
\hline Piperacillin & 236 & 36.4 & 0.0 & 63.6 & $29.9-42.5$ \\
\hline Piperacillin/tazobactam & 533 & 22.7 & 0.7 & 76.6 & $18.9-26.1$ \\
\hline Ceftazidime & 701 & 30.2 & 10.4 & 59.4 & $26.8-33.7$ \\
\hline Imipenem & 675 & 28.9 & 4.4 & 66.7 & $25.5-32.5$ \\
\hline Meropenem & 584 & 21.2 & 5.9 & 72.9 & $18.0-24.8$ \\
\hline Amikacin & 630 & 8.4 & 2.7 & 88.9 & $6.3-10.8$ \\
\hline Gentamicin & 625 & 15.0 & 3.0 & 82.0 & $12.3-18.1$ \\
\hline Tobramycin & 95 & 16.8 & 0.0 & 83.2 & $10.2-26.2$ \\
\hline Ciprofloxacin & 552 & 16.8 & 1.8 & 81.4 & $13.8-20.2$ \\
\hline Levofloxacin & 480 & 22.0 & 9.0 & 69.0 & $18.5-26.1$ \\
\hline
\end{tabular}

aeruginosa (825) were presented in Table 6, where the resistance percentages were changed in between 8.4\% (for amikacin) and $36.4 \%$ (for piperacillin).

\section{DISCUSSION}

Rational usage of antimicrobial agents is a must to struggle with resistance development. For this pourpose, appropriate policies should be developed, like prevention of sale of antimicrobials on the counter, training of public, for clinicians writing guidebooks for logical usage of antimicrobials, etc. On the other hand, precautions for reducing the infection burden should be taken as well, such as following evidence-based guidelines for preventing healthcare-associated infections, training of the health-care workers or for community aquired by vaccinations and some other measures. $(9,12,13)$ Determination of the current situation is one of the steps that should be taken and NAMRSS was established for this pourpose. The results showed that, the bacteria those were followed up were isolated mostly from blood samples, adults, ICU and internal services which are found reasonable.
NAMRSS released first report for the data of 2011. (14) For S. aureus, our data showes that $31.5 \%$ is MRSA, which makes it impossible to use beta-lactam antimicrobials which are first line drugs suggested by CLSI standards, with these isolates. According to CLSI, there is grouping of the antimicrobials in order to combat with antimicrobial resistance by encouragement of usage of primary drugs and limiting the usage of secondary drugs, and nearly one of every three isolates need second group drugs by this data (8). When it was compared to the older data of our country which is presented in Figure 2 (15), the percentages of MRSA was decreased from $43 \%$ to $31.5 \%$, and it may be due to improvement in hospital infection control measures $(12,15,16)$. Another study from our country emphasized similar decrease in MRSA in blood cultures (17). However, it is still higher than many of the European countries and this is a finding that should be emphasized. According to EARS-Net 2011 report, MRSA percentages from 28 countries from Europe were changing in between $0.3 \%-54.6 \%$, and only six of them were higher than our data (18). In the contrary, Mediterranian region showed higher MRSA percentages in five of nine countries than our results (19). A surveillance study 


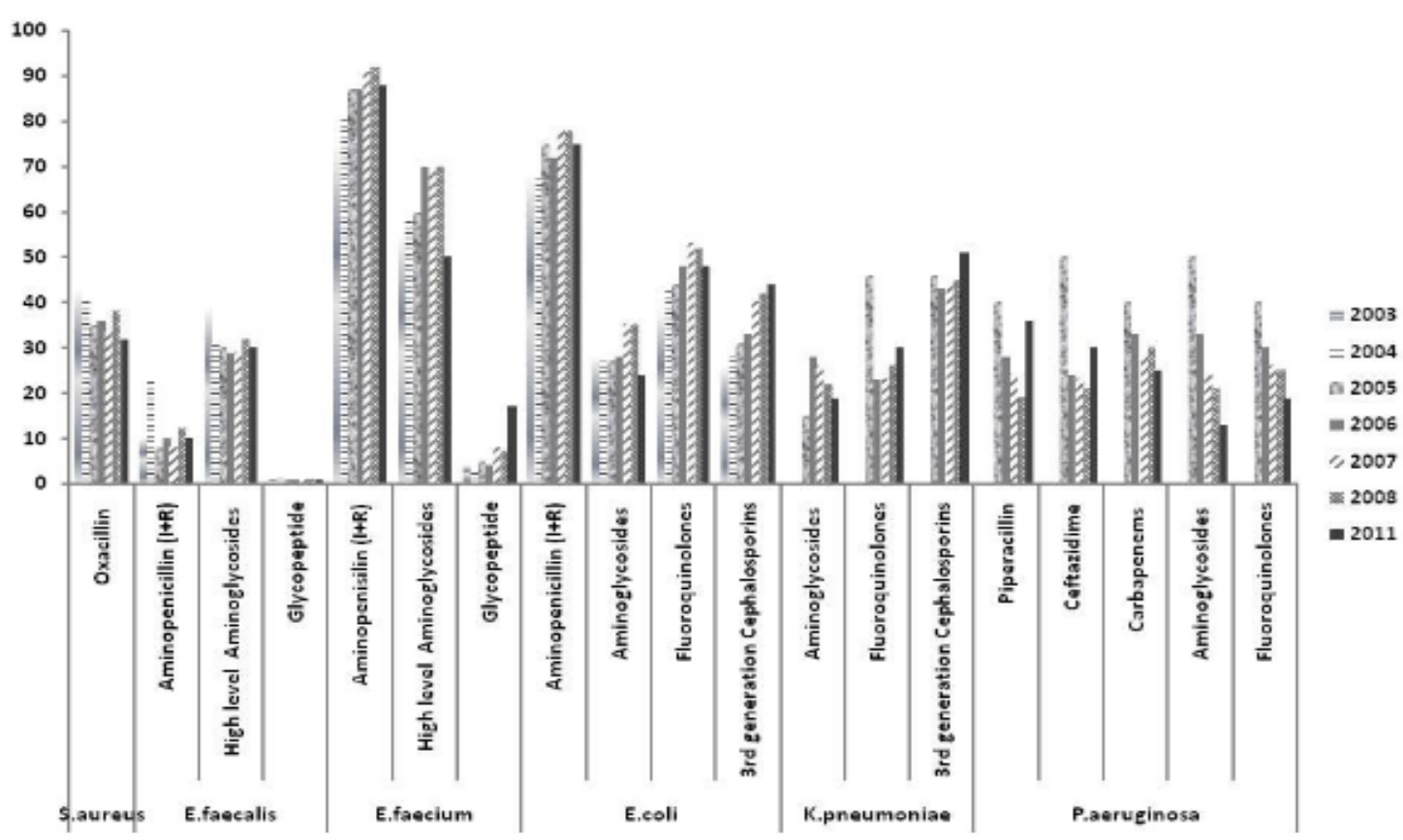

Figure 2. The comparison of data of the selected bacteria and resistance of the selected antimicrobials of NAMRSS in 2011, and the data of Turkey in between 2003-2008 those were sent to EARSS.

from China MRSA was $26.6 \%$, lower than ours (20). The resistance of the second group antimicrobials according to CLSI those were followed were rifampin, linezolid and vancomycin and they were found to be effective $(8,14)$. On the other hand, when focused on MRSA strains, it was observed that the resistance percentage increases for the antimicrobials other than vancomycin. Linezolid resistance was also higher in our country with $1 \%$, which was 0.06 in EARS-Net 2011, that may be due to extensive usage in our country. Rifampin resistance was totaly $1.1 \%$ in 27 country and only Poland $(27.4 \%)$ had a higher percentage than our country (18). Rifampin is used in surgery services for surgical wound treatment extensively, and precautions are required. These findings point out that usage policies need to be developed especially for $S$. aureus with linezolid and rifampin.

For E. faecalis, other than high level ( $\mathrm{HL})$ aminoglycoside, the resistance percentage is lower than $1-10 \%$, which means the antimicrobials mentioned are effective including first line drug ampicillin. Besides, our resistance percentages for $\mathrm{HL}$ aminoglycoside are lower than EARS-Net (2011) for $12 / 20$ of the countries (18). Another study from our country has similar results with $3 \%$ resistance for ampicillin, teicoplanin and vancomycin, and $\mathrm{HL}$ resistance was $16.9 \%$ and $32.4 \%$ for gentamicin and streptomycin, respectively, which are similar to our data (21). On the other hand for $E$. faecium ampicillin have no use, and $\mathrm{HL}$ aminoglycosides are resistant for nearly one of every two strains. However, the other three antimicrobials are found to be effective, but vancomycin resistant isolates are resistant for teicoplanin (95.3\%) and the only option is linezolid for these strains. Most of the European countries have lower resistance levels than ours for vancomycin (18). According to the other study from Turkey, the resistance percentages were slightly higher than NAMRSS except vancomycin (21). When the difference of resistance against time 
was evaluated, nearly all of the antimicrobials showed similar resistance percentages with NAMRSS results for both of the species except $E$. faecium vancomycin resistance, which was changing in between 3-7\% in European Antimicrobial Resistance Surveillance System (EARSS) 2008 report but 17\% in NAMRSS (15). This may be due to extensive usage of vancomycin, especially in amprical therapy, which is an issue to discuss with clinicians. However, there was no statisticaly important difference for the resistance percentages for the other antimicrobials in time.

S. pneumoniae causes local infections and blood stream infections as well as meningitis, which have different breakpoints so that higher resistance percentages are present for the latter (8). Penicillin is a primary drug for S.pneumoniae and by $87.9 \%$ susceptibility, it is still the first choice for nonmeningitis infections (8). Erythromycin is a primary drug as well, but it has no use in treatment unless it is found susceptible in AST, and regarding the dual resistance with penicillin that was observed in this study, it cannot be an alternative drug for penicillin resistant $S$. pneumoniae. Levofloxacin has a higher susceptibiliy percentage than the other second line antimicrobials, suggesting that it is a valid option when there is need to use other than beta-lactam antimicrobials. On the other hand, when the infection is meningitis, none of the beta lactams can be used for empirical treatment. In 2007-2008 data of EARSS those belong to Turkey, penicilin non-susceptible percentages were $26 \%$ and $47 \%$ for blood and CSF, respectively, which were higher for blood and lower for CSF than NAMRSS findings (15). The difference may be due to the smaller sampling of that project or due to usage during the time period in between. When compared with European countries, our findings are within the range but higher than most of the countries (11). When compared with ARMed Project in between 2003-2005, the resistance percentages of penicillin, erythromycin and dual resistance were lower in Turkey than most of the Mediterranian countries, but NAMRSS data showes higher resistance frequency than data of Turkey in ARMed Project, which may be due to extensive usage in time (22). Another study from China showed penicillin resistance $25.7 \%$, and cefuroxime rersistance increase to $38.2 \%$ and $35.3 \%$ for penicillin resistant group, where it was $1.9 \%$ and $1.1 \%$, respectivelyt in penicillin susceptible group, indicating dual resistance (20).

E. coli and K. pneumoniae strains showed similar resistance percentages, and other than amikacin, none of the antimicrobials seem to be useful for empirical treatment. Besides ESBL is positive nearly in one of every two strains, those showe higher resistance percentages for the other antimicrobials and makes therapy more difficult. According to the finding of another project from our country, the ESBL frequency was $39.7 \%$ and $38.8 \%$ for E. coli and K. pneumoniae, respectively, in 2007, which indicates the increase in the percentage in time (24). A Chinese surveillance study found $56.2 \%$ and $42.7 \%$, respectively for the same bacteria, which were similar to our data (20). On the other hand, ampicillin susceptibility in ESBL negative group is found nearly one in every five isolates, so that it is possible to use this first group drup after AST results are available. This fact should be taken into account especially for automated systems, where there is limited opportunity for antimicrobials so that selection of the antimicrobials is of consideration. On the other hand, according to EARSS 2008 report, it was observed that resistance was increasing for aminopenicillins, aminoglycosides, fluoroquinolones and 3rd generation cephalosporins in between 2003 and 2008 in our country (Figure 2) (15). Besides, it was found that resistance percentages were sligthly lower in NAMRSS than EARSS 2008, with exception of fluoroquinolones and 3rd generation cephalosporines for $K$. pneumoniae, that may be due to sampling differences as well as usage differences in time. On 
the other hand, in ARMed Project which was covering 2003-2005, E. coli resistance findings were lower for aminoglicosides, 3rd generation cephalosporins and fluoroquinolones, but similar for aminopenicillins, indicating the increase in resistance in time (23). This increase is valid for European countries, too, even though the percentages are lower than our country. (16) According to EARS-Net 2011, the resistance percentages were lower than ours in most of the countries for most of the antimicrobials. (18) It is necessary to think over these findings and measures should be taken to reduce resistance.

P. aeruginosa results showes that if aminoglycosides and fluoroquinolones are selected for emprical therapy, the chance of success in treatment will increase. On the other hand first group antimicrobials like ceftazidime and piperacillin cannot be used for emprical treatment, but second group drugs like amikacin and ciprofloxacin can. The comparison of data according to time in our country, the resistance percentages seems to get lower, except for piperacillin and ceftazidime for NAMRSS (15). This may be due to the sample differences. Like other bacteria, P.aeruginosa have higher resistance percentages than most of the countries in Europe (18).

\section{CONCLUSION}

The results of all of the antimicrobial agents point out that there is increase in resistance in time, and among the countries in close geographical region, the resistance is higher in our country in most cases. These findings indicate that there is need for developing policies to combat with resistance. This first surveillance results will be a milestone for discussing about these policies and also be useful to compare the results of following NAMRSS in the future to evaluate the benefit of the measures taken.

\section{REFERENCES}

1. Antimicrobial resistance, Global action plan on antimicrobial resistance, http://www.who.int/ antimicrobial-resistance/global-action-plan/en/.

2. Global action plan on antimicrobial resistance, http: / / www. who.int/antimicrobial-resistance/ publications/global-action-plan/en/.

3. Aktaș D, Aydemir ş, Bayram M, Bayramoğlu G, Ceyhan I, Çöplü $N$ ve ark. Ulusal Antimikrobiyal Direnç Suveyans Sistemi laboratuvar testleri, kalite kontrolü ve kalite güvencesi standart uygulama prosedürleri ve WHONET yazılım programı. Ankara. Şubat 2011 (National Antimicrobial Resistance Surveillance System Laboratory Tests, Quality Control and Quality Assurance Standard Operating Procedures and WHONET software, Ankara, February 2011) ISBN: 978-975-590-347-7. www. uamdss.thsk.gov.tr.
4. SURVEILLANCE REPORT. Antimicrobial resistance surveillance in Europe Annual report of the European Antimicrobial Resistance Surveillance Network (EARS-Net) 2010. http://ecdc.europa. eu/en/publications/_layouts/forms/Publication DispForm. aspx?List $=4 \mathrm{f} 55 \mathrm{ad} 51-4 \mathrm{aed}-4 \mathrm{~d} 32$-b960af70113dbb90\&ID=502.

5. Central Asian and Eastern European Surveillance of Antimicrobial Resistance, Annual Report 2014. World Health Organization, Regional Office for Europe, 2015. http://www.euro.who. int/_data/assets/pdf_file/0006/285405/CEASERSurveillance-Antimicrobial-Resistance 2014. pdf?ua=1.

6. Gözalan A, Çöplü N, Aktaș D, Şimșek H, Bahar Erdem G, I Mumcuoğlu. Performance evaluation of the microbiology laboratories in Turkey for culture and antibiotic susceptibility tests and the selection of laboratories to provide data for National Antimicrobial Resistance Surveillance System: Questionnary application. Turk Hij Den Biyol Derg: 2015; 72(3): 175 - 182. 
7. Antimicrobial Resistance Surveillance Questionnaire for Assessment of National Networks WHO/CDS/ CSR/RMD/2003.1. World Health Organization. ht tp: / / www. who.int / drugresistance / whocdscsrrmd20031.pdf?ua $=1$.

8. Clinical and Laboratory Standards Institute, Performance Standards for Antimicrobial Susceptibility Testing. M100S21 Vol.31 No 1, January 2011.

9. WHO Collaborating Centre for Surveillance of Antimicrobial Resistance www.whonet.org.

10. Akbas E, Cöplü N, Simsek H, Esen B, Sezgin B. Laboratory evaluation of susceptibility tests for National Antimicrobial Resistance Surveillance System (NAMRSS) in Turkey. Turk Hij Den Biyol Derg, 2018; 75(1): 1-12. DOI ID : 10.5505/ TurkHijyen.2018.89166.

11. Çöplü N, Gülay Z, Temel F, Şimșek H, Göl N, Aktaș D. The First External Quality Assurance Laboratory Proficiency Assesment Study of National Antimicrobial Resistance Surveillance System in Turkey. Turk Hij Den Biyol Derg, 2018; 75(2): 117 126 doi: 10.5505/TurkHijyen.2018.10437.

12. Loveday HP, Wilson JA, Pratt RJ, Golsorkhi M, Tingle A, Bak A, et. al. epic 3: National Evidence-Based Guidelines for Preventing Healthcare-Associated Infections in NHS Hospitals in England. J Hosp Infect, 2014, 86 (Supp 1), 1-70. http://dx.doi. org/10.1016/S0195-6701(13)60012-2.

13. Winsor $G$, Patel $M$. Combined infection trainingshould we be concerned about its impact on infection prevention and control training of microbiologists in the UK? J Hosp Infect 2015, 91 (4), 302-305. http://dx.doi.org/10.1016/j. jhin.2015.09.003.

14. National Antimicrobial Resistance Surveillance System 2011 Annual Report. file:///C:/ Documents\%20and\%20Settings/hst/Belgelerim/ Downloads/UAMDSS_2011_Raporu.pdf.

15. European Antimicrobial Resistance Surveillance System, Annual Report 2008 On-going surveillance of S.pneumoniae, S. aureus, E.coli, E. faecium, $E$. faecalis, $K$. pneumoniae, $P$. aeruginosa. http: / / ecdc.europa.eu/en/healthtopics/ antimicrobial-resistance-and-consumption/ antimicrobial_resistance/publications-documents/ Documents/2008_EARSS_Annual_Report.pdf.
16. Gagliotti C, Balode A, Baquero F, Degener J, Grundmann H, Gür D, et.al. The EARS-Net Participants (Disease Specific Contact Points for AMR). Escherichia coli and Staphylococcus aureus: bad news and good news from the European Antimicrobial Resistance Surveillance Network (EARS-Net, formerly EARSS), 2002 to 2009. Euro Surveill. 2011;16(11):pii=19819. Available online: http: / / www.eurosurveillance.org/ViewArticle. aspx?Articleld=19819.

17. Kızılarslanoğlu MC, Sancak B, Yağcı S, Hasçelik G, Ünal S. Evaluation of methicillin-resistant Staphylococcus aureus bacteremia and comparison of prognosis according to vancomycin MIC values: Experience of the Last Ten Years. Mikrobiyol Bul 2013; 47(2): 199-210.

18. Surveillance Report Antimicrobial resistance surveillance in Europe 2011

http://ecdc.europa.eu/en/publications/_layouts/ forms/Publication_DispForm. aspx?List=4f55ad51 4aed-4d32-b960-af70113dbb90\&ID=719.

19. Borg MA, de Kraker M, Scicluna E, van de SandeBruinsma N, Tiemersma E, Monen J et. al. Prevalence of methicillin-resistant Staphylococcus aureus (MRSA) in invasive isolates from southern and eastern Mediterranean countries. J Antimicrob Chemother 2007, 60, 1310-1315. doi:10.1093/jac/ dkm365.

20. Yang $Q, X u Y$, Xie $X$, Wang $H$, Hu $Y$, Ni $Y$, et.al. Antimicrobial resistance surveillance on hospitaland community-acquired pathogens in 10 teaching hospitals in China. Chinese Journal of Nosocomiology, 2009, 09 http://en.cnki.com.cn/ Journal_en/E-E055-ZHYY-2009-09.html .

21. Gülmez D, Hasçelik G. Comparison of microdilution method and phoenix automated system for testing antimicrobial susceptibilities of Enterococcus Strains. Mikrobiyol Bul, 2011;45(1):21-27.

22. Borg MA, Tiemersma E, Scicluna E, van de SandeBruinsma N, de Kraker M, Monen J, et al. Prevalence of penicillin and erythromycin resistance among invasive Streptococcus pneumoniae isolates reported by laboratories in the southern and eastern Mediterranean region. Clin Microbiol Infect 2009; 15: 232-7.

23. Borg MA, van de Sande-Bruinsma N, Scicluna $\mathrm{E}$, de Kraker M, Tiemersma E, Monen J, et al. Antimicrobial resistance in invasive strains of Escherichia coli from southern and eastern Mediterranean laboratories. Clin Microbiol Infect 2008; 14: 789-796. 